\title{
HUNGARIAN SECONDARY SCHOOL STUDENTS' PHYSICAL ACTIVITY PATTERNS WITH REGARD TO GENDER
}

\author{
Veronika Végh \\ University of Pecs, Hungary \\ E-mail: vghveronika@yahoo.com \\ Gergely Horzsa \\ Corvinus University, Hungary \\ E-mail: horzsagergely@gmail.com
}

Zsolt B. Nagy

Guppi Consulting Ltd, Hungary

E-mail: dr.nagy.zsolt@gmail.com

Gábor Elbert, Henriette Pusztafalvi

University of Pecs, Hungary

E-mail: elberteam@gamil.com, pusztafalviheni@gmail.com

\begin{abstract}
The rationale behind the research is the Hungarian government's decision to introduce daily physical education lessons in schools. The system was expanded to all grades by the 2016/2017 academic year. It aims to improve students' health consciousness and sports habits. Hungarian high school students 'physical activity, participation in competitive sport, body mass index and lifestyle determiners were examined with regard to gender. Altogether, 333 students completed the anonymous questionnaire, their average age was 16.12. Their Body Mass Index (BMI) was used to estimate the prevalence of obesity. The association between BMI and lifestyle determiners was analysed. $63.8 \%$ of girls and $70.4 \%$ of boys exercise daily or several times a week. Girls love individual sports, while boys would rather choose team sports. More boys participate in competitive sports (26.2\%) than girls (16.5\%). Both genders' biology marks are better than those of students who do no sport. $46.81 \%$ of girls and $27.59 \%$ of boys have been on a slimming diet, and a high percentage of girls were on a slimming diet, even those with a normal BMI. The results suggest that despite having five physical education (PE) lessons every week, students want to get more exercise. However, a lack of time and fatigue prevents them from doing so. Most children chose PE as their favourite subject, but out of all sporting venues it is at school that they like doing sport the least. Keywords: physical activity patterns, eating habits, physical education.
\end{abstract}

\section{Introduction}

Physical activity unquestionably plays a vital role in people's lives. It is crucial for normal physical and mental development, and regular physical exercise is one of the key components of childhood obesity prevention programmes (Kropski, Keckley, \& Jensen, 2008). It reduces the risk factors for various diseases (Rowland, 2007), and it improves students' academic performance as well. Previous studies indicate that doing regular physical exercise is associated with better marks in English and mathematics. The extent to which they are related 
Veronika VÉGH, Gergely HORZSA, Zsolt B. NAGY, Gábor ELBERT, Henriette PUSZTAFALVI. Hungarian secondary school students' physical activity patterns with regard to gender

PROBLEMS

OF EDUCATION

IN THE $21^{\text {st }}$ CENTURY Vol. 76, No. 5, 2018

740

depends on gender and socioeconomic status (Dyer, Kristjansson, Mann, Smith, \& Allegrante, 2017). Although previous studies showed that higher physical activity levels are associated with academic achievement, it was unclear whether the physical activity itself or the team sport element caused this positive link. Among girls, team sport participation and the physical activity itself were both associated with better academic achievement, while among boys only team sport participation was associated with better marks (Fox, Barr-Anderson, Neumark-Sztainer, $\&$ Wall, 2010). Many factors play an important role in the students' lifestyles, diet and physical activity habits. The more teachers and educators know about these factors, the better chance they have of encouraging them to lead healthier lifestyle by offering healthier meals in schools or more opportunities to do sport. Interviews were carried out with 70 students in alternative secondary schools (Kubik, Lytle, \& Fulkerson, 2005). The food choices and the chosen physical activities were affected by several factors, such as time, cost, availability and convenience. Access to healthy meals and sport is sometimes hindered in schools. According to the literature, social support from family members, friends, teachers and role models increases the likelihood that students will eat healthy food and do physical activities. Socioeconomic status also clearly plays an important role in enhancing students' healthy eating habits and increasing the amount of physical activities they carry out (Kubik, Lytle, \& Fulkerson, 2005). Many studies have been published which document the differences between the responses of girls and those of boys. Secondary school boys have a more positive attitude towards physical education than girls (Koca \& Demirhan, 2004). Girls had lower self-esteem, and generally the high school age group scored lower on self-esteem than the elementary school students or university students (Frost \& McKelvie, 2004). The connection between weight management and physical activity was examined, vegetable and fruit consumption, and other lifestyle determiners, such as smoking, among 15349 American high school students. Quarter of the students were overweight or almost overweight (25\%). Altogether, $43 \%$ of the students were trying to lose weight, while $19 \%$ of them were satisfied with their current weight. Boys were more likely to be overweight than girls, however girls were more likely to try to lose weight. Among girls, the attempt to loose weight is associated with smoking, intensive physical activities and strengthening exercises, while among male students, it is linked to intensive physical activity, strengthening exercises and eating more than 5 servings a day of fruit and vegetables. Those students who want to maintain their body weight (g: $62 \%$, b: $41 \%$ ) combine physical exercise with a low fat and low calorie diet. Unhealthy weight control strategies like tablets, fasting, vomiting, were used by $32 \%$ of girls and $17 \%$ of boys (Lowry et al., 2002). It is not only the age of the students, role models and parental patterns, but the type of physical activity that has a different effect on females and males. The effect of youth resistance training was studied among 11 and 13 year old students. This mode of exercise enhances muscle strength and endurance because the students need to work against resistance. This physical activity enhances students' health and fitness and improves their performance in sport (Faigenbaum et al., 2009). Obesity is often associated with a sedentary lifestyle, and it affects more and more young people all over the world. It increases the risk of cancer, diabetes, cardiovascular diseases and other diseases, and therefore people are fighting against it in many ways. The chances of physically inactive students becoming overweight is much higher than among their physically active peers. An experiment was carried out recently on the Balearic Islands, the results of which proved this connection (Muntaner-Mas, Vidal-Conti, Cantallops, Borrás, \& Palou, 2017). In order to establish or maintain a healthy lifestyle, it is important that students have adequate health literacy. The correlation between health literacy tests among high school students and participation in club sport was examined, taking into consideration students' gender, age, social status, performance at school and physical activity level. The health literacy of physically active (sport 6 to 7 times a week) male and female students (aged 13 and 15), students with at least a moderate level of achievement at school and middle or upper class students was higher if they were members of a sport club. As 
regards health literacy, activity within sport clubs had a particularly positive effect on students with a low or moderate level of school achievement. The more social groups a sporting facility is able to admit, the more it contributes to an equal level of health literacy (Paakkari, Kokko, Villberg, Paakkari, \& Tynjala, 2017). Sports clubs are therefore an important factor, because they promote students' health literacy and because most students find it important to be the member of a group when doing sport. Icelandic adolescents' physical activity level and participation in sport clubs were examined in 1992, 1997, 2000 and 2006. On balance, the results suggest a significant increase in physical activities and participation in sport clubs among both genders over the past decade. However, more than half of the students polled do not dedicate as much time to sport as recommended, and less than one third of them achieve the recommended level of physical activity in the sports club. Health education should be a priority in order to allow teenagers to dedicate enough time to physical activities (Paakkari et al. 2017). Although the benefits of sports for health are well-known, the dangers of competitive sports have also been the focus of some studies which claimed that competitive sports might affect late teenage and adult behaviour. The results of a study involving 970 senior high school students suggest that those who pursued at least one form of competitive sport in the 12th grade were more prone to unlimited alcohol consumption during the two weeks preceding the study 1 to 4 years after graduation. Furthermore, those who participated in contact sports were more prone to unlimited alcohol consumption and marijuana abuse in the month prior to the study (Veliz et al., 2017) . These data confirm that it is vital that students' health consciousness is thoroughly understood along with their sports habits, eating habits and lifestyle. It is important that the difference between boys and girls is understood and that the number of overweight students is assessed. By evaluating the current situation and health education lessons, schools may be able to improve the health-consciousness of the next generation.

\section{Physical Education in Hungary}

Paragraph 11 of $\S(6)$ A 27 of the Act on Public Education (PE) gradually phased in daily PE lessons in the first, fifth and ninth grades. PE as a subject and sport in secondary schools aim to expand students' knowledge of sport and physical activities by developing various skills. Besides improving students' adaptability and responsibility for their own health, this subject also teaches them how to combine sport and studying. Moreover, they experience the beneficial physiological effects of physical activities. The core curriculum of the subject establishes the pillars of students' health-conscious adult lives later on ${ }^{1}$. Based on data reported by educational institutions of Hungary about health conditions of students of different age groups between $7-18$, a study by OGYEI shows that a $10 \%$ of Hungarian primary and secondary school student can be described as being obese. Hypertension affects $2.7 \%$ of 12 th graders (whereas only $0.21 \%$ of those in 2 nd grade, the value rises gradually by aging). It also turned out that $5.6 \%$ of students participate in special PE of some kind or are exempted from PE lessons. (OGYEI 2014). After the reform of PE in Hungary in 2012, several researches dealt with the opportunities and limitations within the new system. Besides recognising the positive effect of the increase in number of PE lessons on children's physical culture and health, they raise attention to the fact that the infrastructure (both physical and human) does not provide an opportunity to high-quality education (Meszlényi, Borbélyi, Seregi, Morvay-Sey, \& Rétsági, 2017). Though the participation of students in $5 \mathrm{PE}$ occasions a week is compulsory since the reform, based on a survey among Hungarian schools (institutional level), it is argued that a third of students do not attend more than 3 times a week as being exempted for participating in extracurricular sport activities (Morvay-Sey \& Rétsági, 2017). Németh (2014), based on data analysis of Word Health Organisation (WHO) coordinated cross-national research HBSC (Health Behaviour in

\footnotetext{
1 http://kerettanterv.ofi.hu
} 
Veronika VÉGH, Gergely HORZSA, Zsolt B. NAGY, Gábor ELBERT, Henriette PUSZTAFALVI. Hungarian secondary school students' physical activity patterns with regard to gender

OF EDU

IN THE $21^{\text {st }}$ CENTURY Vol. 76, No. 5, 2018

School-Aged Children) found no difference between those participating in the new PE system and others considering their health status. The authors, just like Uvacsek and Pusztafalvi (2018) in another, newer study based on HBSC data, show a robust difference between volumes of sport activities between boys and girls (latter group doing less sport). However, besides health status and behaviour, in this research children's attitudes were not measured.

\section{The Purpose of the Research}

Daily PE lessons can have a huge effect on the sporting and lifestyle habits of the students as they are exposed to it five times a week. It is important for teachers and professionals to know more about the students' current sporting and lifestyle habits and opinions and preferences about physical activities to best fit the curriculum and the teaching practices according to the students' needs.

On one hand, the present research focused on the Hungarian secondary school girl and boy students' love for sport, and it aimed at mapping the frequency of their physical activities. On the other hand, the research examined the girls' and boys' motivation for doing sports, competitive sport participation, alcohol consumption and smoking habits as well as their eating habits.

The present research aimed to answer the following questions:

1. How often do girls and boys perfom physical activities?

2. What is their self-reported love towards sports?

3. How satisfied the Hungarian girl and boy secondary school students are with the frequency of the physical exercise they perform? If they would like to do more sports, what are the factors that hinder them doing more physical activity?

4. What are the main motivating factors for doing sports for the students?

5. What kind of activities are preferred by the girl/boy students?

6. Are there gender differences in terms of healthy eating habits, BMI, smoking habits and alcohol consumption of the students?

\section{Methodology of Research}

\section{General Background}

By the academic year of 2016/2017, the Paragraph 11 of $\S(6)$ A 27 of the Act on Public Education has been expanded to all secondary school classes in Hungary, which introduced daily PE lessons for them. The experiment involved 333 secondary school students altogether, who volunteered to fill in an online anonymous questionnaire about their lifestyle habits.

\section{Sample Selection}

In total, 333 Hungarian secondary school students, 188 girls (54\%) and 145 boys (43.5\%), responded to the anonymous online questionnaire. Their average age was $16.12(S D: 1.52)$.

All of the respondents had 5 PE lessons every week, more than half of the respondents were studying in gymnasiums (53.8\%) while the rest of the students were attending vocational schools. In Hungary, secondary school usually lasts for 4 years in classes 9-12, in case of vocational school there might be an additional year, referred as class 13 . Table 1 shows the students' classes with the gender distribution. Respondents were provided with a description of the research at the beginning of the questionnaire and they were informed about the questionnaire's question types, anonymity and the statistical methods. 
Veronika VÉGH, Gergely HORZSA, Zsolt B. NAGY, Gábor ELBERT, Henriette PUSZTAFALVI. Hungarian secondary school students' physical activity patterns with regard to gender

Table 1. Students' distribution among the classes.

\begin{tabular}{llll}
\hline Class & Students' percentage $(\%)$ & Girls $(\%)$ & Boys $(\%)$ \\
\hline 9. & 39.1 & 41.4 & 36.1 \\
\hline 10. & 24.2 & 23.7 & 25.0 \\
\hline 11. & 21.8 & 22.6 & 20.8 \\
\hline 12. & 11.8 & 8.6 & 16.0 \\
\hline 13. & 3.0 & 3.8 & 2.1 \\
\hline
\end{tabular}

Instrument and Procedures

Students were asked to complete anonymous, online questionnaire ${ }^{2}$, which aimed at collecting general information, such as gender, year of birth, type of secondary school they are attending, their class and their favourite subject. Their physical activity patterns, frequency of doing sports, competitive sport participation, motivation for doing sport were also asked. Using a 6-point Likert scale, we were able to gather information on students' opinions of sports, where 6 signified complete agreement and 1 signified a lack of agreement. Using a data reduction method, this information was categorised into four factors (activity, entertainment, competition and body-shaping). Furthermore, the questionnaire contained important information about the students' eating habits, with regard to the current study. Their alcohol consumption and smoking habits were also mapped. Using their own weight and height data, the respondents' body mass index was calculated, which was used to estimate the prevalence of obesity. The questionnaire was approved by the Regional Research Ethics Committee of the Pécs. Students received the questionnaire link in class.

\section{Data Analysis}

In order to examine the effects of daily PE lessons, students' sporting habits and lifestyles from various perspectives were analyzed. IBM SPSS Statistics version 20 and Microsoft Excel 2010 software were applied to analyse the data and to create graphs. Descriptive statistics were used mainly. The confidence level used was $95 \%$.

\section{Results of the Research}

\section{Love of Sport and Frequency of Physical Activities}

In order to answer the first question ("How often do girls and boys perform physical activities and what is their self-reported love towards sports?') their favourite subjects, their self-reported love for sport and the frequency of their physical activities were looked at.

When asked about their favourite subjects, physical education was in the top three among both high school boys and girls. For 17.6\% of girls English came first, followed by PE (17.0\%) and art (16.5\%). For boys, PE was the absolute favourite (24.8\%), whereas information technology came second (17.2\%), followed by mathematics (12.4\%). As attested by Figure 1, 53.8\% of the girls and $64.8 \%$ of the boys polled said they had a positive opinion of sports. Based on the answers of the students in the study, girls are more indifferent to sports than boys (girls 27.7\%

2 http://www.sporteseletmod.hu/letoltes/KerdoivMSEpiac.pdf 
Veronika VÉGH, Gergely HORZSA, Zsolt B. NAGY, Gábor ELBERT, Henriette PUSZTAFALVI. Hungarian secondary school students' physical activity patterns with regard to gender

OF EDUCA

IN THE $21^{\text {st }}$ CENTURY Vol. 76, No. 5, 2018

744

and boys $18.6 \%$ ) and more girls than boys claimed that if they had to choose they would say that they did not like sport (girls $12.2 \%$ and boys 6.2 ).

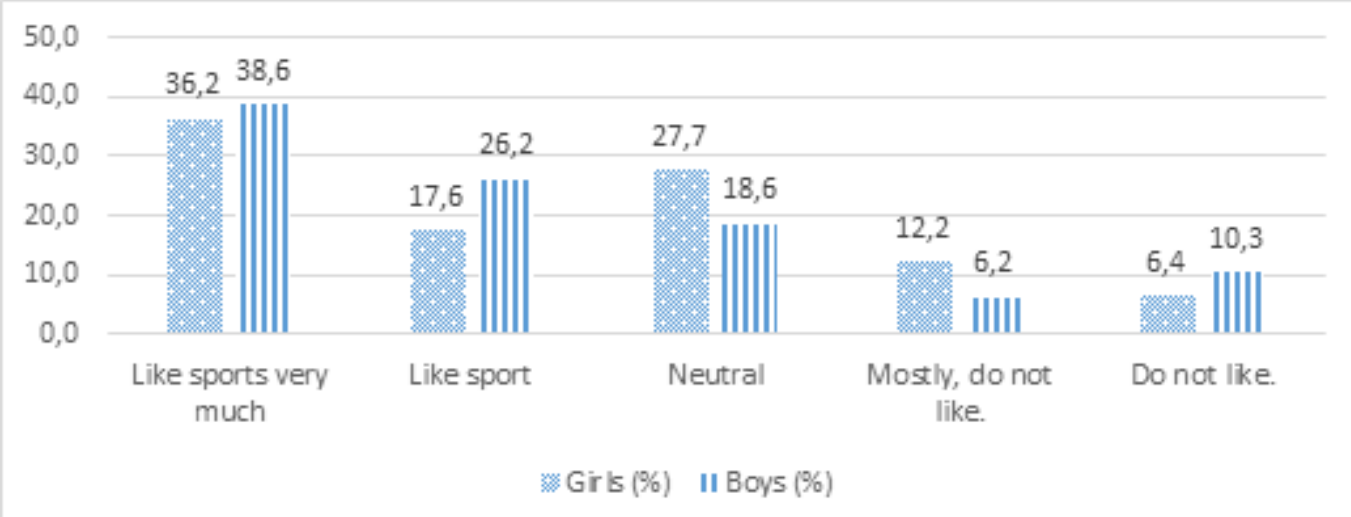

Figure 1. Differences between boys and girls regarding their love of sport (\%).

More than $50 \%$ of boys and girls do sport every day or several times a week (girls $63.8 \%$ and boys $70.4 \%$ ) There are a small number of boys and girls who do sport once a week (girls $11.7 \%$ and boys $9.7 \%$ ). Approximately the same percentage of boys do sport every day (34.5\%) or several times a week $(35.9 \%)$, whereas among girls there was a bigger difference $(29.3 \%$ and $27.8 \%$, respectively). $16.5 \%$ of girls and $13.1 \%$ of boys claimed that they do sport less than once a week. A mere $4.8 \%$ of girls and $6.9 \%$ of boys exclude sport completely from their lives. When answering the second question ("Are Hungarian girl and boy secondary school students satisfied with the frequency of the physical exercise they perform? If not, what are the factors that hinder them doing more physical activity?'), it has been found that $75.5 \%$ of girls and $64.8 \%$ of boys want to do more sport than they currently can. They had various reasons for their dissatisfaction, including a lack of time (girls 59.4\% and boys 54.6\%), tiredness (girls 24.8\% and boys $21.8 \%$ ). A lack of money (girls 5.5\% and boys $7.6 \%$ ) and a lack of company (girls $5.5 \%$ and boys $5 \%$ ) also prevent some students from getting as much exercise as they would like. $0.6 \%$ of girls and $2.5 \%$ of boys feel that their families prevent them from doing it. The rest are satisfied with their current sports habits and do not wish to spend more time doing exercise (girls $24.5 \%$ and boys $35.2 \%$ ).

It has been indicated in the scientific literature (Dyer et al, 2017) that the frequency of physical activities can affect the student's academic achievement, a positive correlation was found between the students' biology grades and the frequency of their sport related activities (Pearson correlation: .134, $p=.014$ ).

\section{Activities and Motivation for Sport}

To provide a comprehensive answer for the third question ("What are the main motivating factors for doing sports for the students? "), the students answers were descriptively analysed.

The main motivations for doing sport was having fun (boys $28.3 \%$ and girls $22.9 \%$ ) and looking good (girls $22.3 \%$ and boys $18.6 \%$ ). Table 2 shows that more girls (13.8\%) do sport in order to lose weight than boys $(6.9 \%)$. Girls were also more motivated by health preservation, too (girls $16.5 \%$ and boys $11.7 \%$ ). However, competition was a greater motivation for boys (boys $13.1 \%$ and girls $10.1 \%$ ). Parents had a minimal role to play in motivation and there were students who were not motivated to do sport by anything (boys $13.8 \%$ and girls $8.5 \%$ ). 
Veronika VÉGH, Gergely HORZSA, Zsolt B. NAGY, Gábor ELBERT, Henriette PUSZTAFALVI. Hungarian secondary school students' physical activity patterns with regard to gender

Table 2. Girls and Boys motivation for doing sports.

\begin{tabular}{lll}
\hline Motivating factor & Girls $(\%)$ & Boys (\%) \\
\hline Having fun & 22.9 & 28.3 \\
\hline Health prevention & 16.5 & 11.7 \\
\hline Competition & 10.1 & 13.1 \\
\hline Parents & 2.7 & 2.1 \\
\hline Looking good & 22.3 & 18.6 \\
\hline Losing weight & 13.8 & 6.9 \\
\hline Nothing & 8.5 & 13.8 \\
\hline Other & 3.2 & 5.5 \\
\hline
\end{tabular}

When answering the fourth question ('What kind of activities are preferred by the girl/ boy students?'), the descriptive statistics showed that most students run on a regular basis (girls $22.9 \%$ and boys $27.8 \%$ ). Aerobics and yoga were, not surprisingly, more popular with girls $(11.7 \%$ and $4.8 \%)$. No boys chose aerobics and very few mentioned yoga as their favourite activity (boys $0 \%$ and girls $1.4 \%$ ). However, $22.9 \%$ of boys said football was their favourite activity, whereas only $9 \%$ of girls chose this sport. Horse-riding was $6 \%$ more popular with girls (girls $7.4 \%$ and boys $1.4 \%$ ). $27.1 \%$ of girls and $25.3 \%$ of boys pursue other physical activities.

Both boys and girls liked doing sport with friends the most (girls $45.7 \%$ and boys: $51 \%$ ). More girls than boys like to do sport alone (girls $27.7 \%$ and boys $13.8 \%$ ). Team sports, however, show the opposite tendency (boys 22.8\% and girls 17.6\%).

As far as sporting venues are concerned, $36.2 \%$ of girls like to do sport outdoors and $34 \%$ of them go to the gym. $22.3 \%$ do sport at home and a mere $4.8 \%$ like doing sport at school. Boys show a similar tendency, but $44.1 \%$ of them like to do exercise outdoors. They also like going to the gym (31.7\%). Only $11 \%$ of boys like to do physical activities at home, which is half the percentage of girls. However, they do not really like doing sport at school either (5.5\%).

Many boys have pursued competitive sport at some point (44.8\%), $26.2 \%$ currently do and $29 \%$ have never tried it, while $40.4 \%$ of girls have tried competitive sport at some point and a mere $16.5 \%$ currently do. Therefore, a higher percentage of girls (43.1\%) have never tried competitive sport.

In order to be able to answer the fifth question ("Are there gender differences in terms of healthy eating habits, BMI, smoking habits and alcohol consumption of the students?') first of all, the answers were observed for the question: "How important is healthy nutrition to you?'.

As Table 3. indicates more girls consider it important $(30.3 \%)$ or very important $(16.5 \%)$ than boys $(27.6,15.9)$, although the majority of the students only occasionally pay attention to healthy eating (girls: $33.5 \%$, boys: $42.1 \%$ ).

Table 3. Self- reported importance of healthy nutrition of girls and boys.

\begin{tabular}{lll}
\hline Importance of healthy nutrition & Girls $(\%)$ & Boys (\%) \\
\hline Very important & 16.5 & 15.9 \\
\hline Important & 30.3 & 27.6 \\
\hline I pay attention if I have time. (Occasionally) & 33.5 & 42.1 \\
\hline I do not care. & 19.7 & 14.5 \\
\hline
\end{tabular}


Veronika VÉGH, Gergely HORZSA, Zsolt B. NAGY, Gábor ELBERT, Henriette PUSZTAFALVI. Hungarian secondary school students' physical activity patterns with regard to gender

OF EDUCA

IN THE $21^{\text {st }}$ CENTURY Vol. 76, No. 5, 2018

Vol. 76, No. 5, 2018

The competitive sport participation and healthy eating were observed together. As Figure 2 suggests, there were more outliers among girls. $48.86 \%$ of girls who have pursued competitive sport at some point only pay attention to healthy eating when they have the time and $21.05 \%$ find it important. $17.11 \%$ consider it vital and $13.16 \%$ ignore it. Of the girls who have never tried competitive sport, $18.52 \%$ find healthy eating vital, $34.57 \%$ find it important, $37.04 \%$ only pay attention to it when they have the time and $9.88 \%$ ignore it. $9.68 \%$ of girls who are currently pursuing competitive sport find healthy eating vital, $48.39 \%$ find it important, $32.26 \%$ only pay attention to it when they have the time and $9.68 \%$ ignore it. Among boys the distribution was more uniform, however the percentage of those who ignored healthy eating was higher in all three categories. $10.77 \%$ of boys who have tried competitive sport at some point consider healthy eating vital, $30.77 \%$ find it important and $33.85 \%$ pay attention to it when they have the time. $24.62 \%$ ignore it. Boys who have never pursued competitive sport show a similar tendency. (14.29\%; 26.19\%; 33.33\%; and 26.19\%). A higher percentage of boys who are currently doing competitive sport find healthy eating vital $(26.32 \%), 18.42 \%$ believe it is important, $28.95 \%$ pay attention to it when they have the time and $26.32 \%$ ignore it.

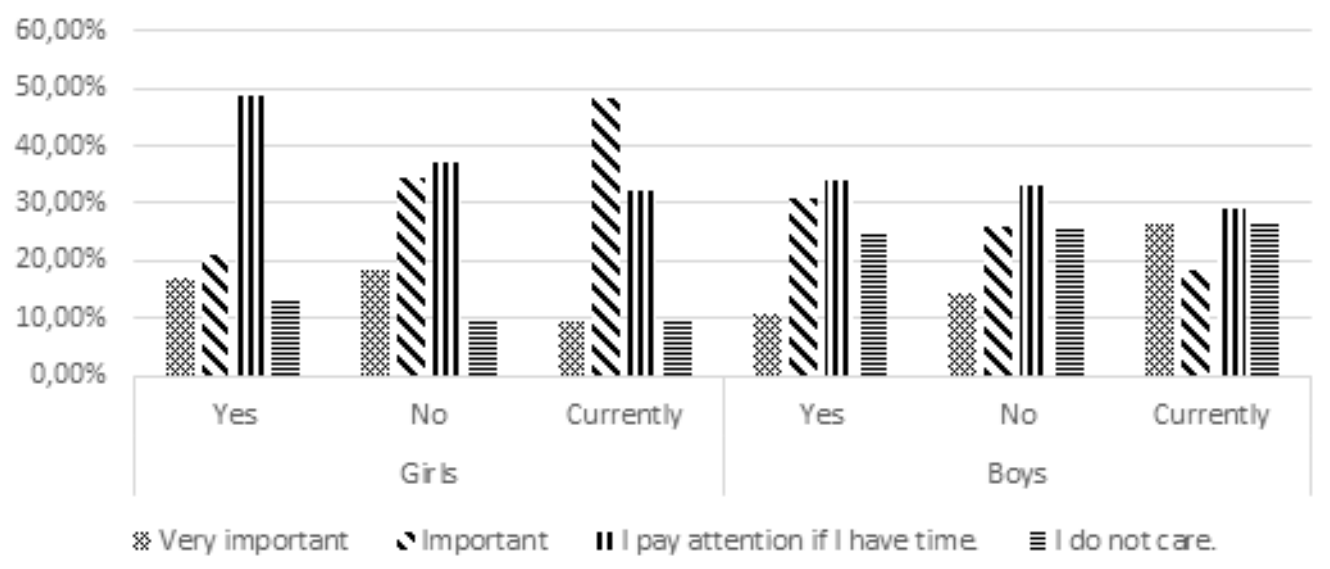

\section{Figure 2. Correlation between competitive sport and healthy eating with regard to gender.}

Positive correlation was found between the given answers on a 6-point Likert scale for the following sentences: 'I do a sport only if there is a possibility for competition' and 'I do sports regularly in order to maintain my health'. (Pearson correlation: .243, $p=.000007$ ).

Based on our data, the majority of boys and girls do not smoke. In all three cases, the proportion of boys and girls who have never smoked was above $60 \%$ (those who have pursued competitive sport at some point: boys $61.84 \%$ and girls $60 \%$; those who have never tried competitive sport: boys $74.07 \%$ and girls $69.05 \%$; those who are currently doing competitive sport: boys $70.97 \%$ and girls $78.95 \%$ ). Most of the boys who smoke several times a day are the ones who have pursued competitive sport at some point (19.74\%). 9.68\% of boys who are currently doing competitive sport and $6.17 \%$ of boys who have never tried competitive sport claim they smoke several times a day. Girls show a similar tendency: $18.46 \%$ of girls who have pursued competitive sport at some point, $5.26 \%$ of girls who are currently doing competitive sport and 4.76 of girls who have never tried competitive sport smoke several times a day. When examining the smoking habits and a weight-losing lifestyle, we found that $64.7 \%$ of girls never smoke and $10.3 \%$ smoke on a daily basis, whereas these percentages for boys were $72 \%$ and $16.2 \%$, respectively. As regards alcohol consumption (Figure 3.), there is larger number of abstinent boys than girls (boys who have pursued competitive sport: $27.63 \%$, girls who have pursued 
Veronika VÉGH, Gergely HORZSA, Zsolt B. NAGY, Gábor ELBERT, Henriette PUSZTAFALVI. Hungarian secondary school students' physical activity patterns with regard to gender

competitive sport: $21.54 \%$; boys who have never tried competitive sport: $41.98 \%$, girls who have never tried competitive sport: $26.19 \%$; boys who are currently doing competitive sport: $41.94 \%$, girls who are currently doing competitive sport: $28.95 \%$ ).

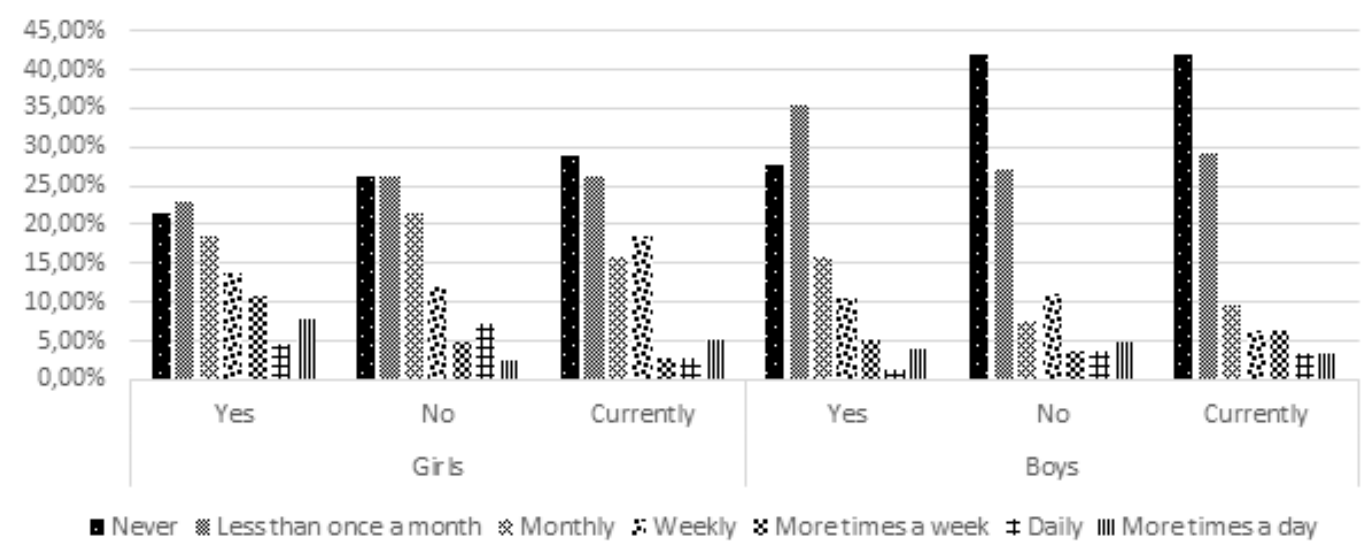

\section{Figure 3. Percentages of girls' and boys' alcohol consumption frequency and competitive sport participation.}

It has also been examined how many students consider their diet as a motivation for sport, and whether they pay attention to healthy eating and $14.7 \%$ of girls who are motivated by a desire to lose or maintain weight find healthy eating vital, $29.4 \%$ consider it important, $44.1 \%$ only pay attention to it when they have the time and $11.8 \%$ ignore it. Among boys these percentages were $18.9 \%, 29.7 \%, 27.0 \%$ and $24.3 \%$, respectively (Figure 4.).

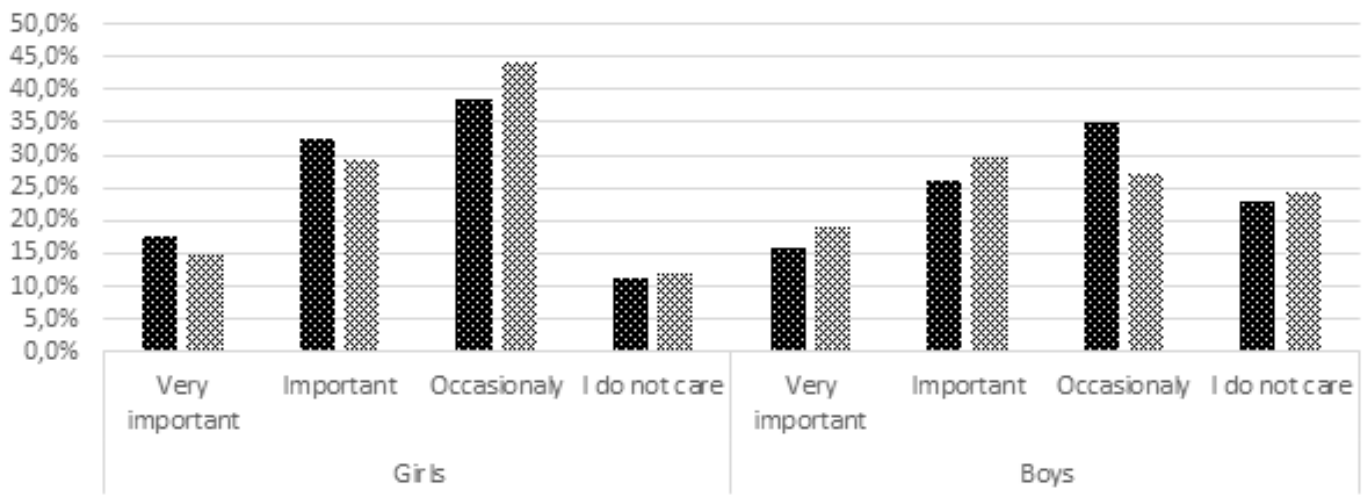

Motivation for sport: other $\quad$ * Motivation for sport: to lose weight/ to look good

Figure 4. Sport motivation and healthy eating habits with regard to genders.

More than half, $55.9 \%$ of girls who do sport in order to lose weight or to look good do not consider themselves obese, $25 \%$ say that they are moderately obese and $19.1 \%$ feel that they are obese. For boys whose main motivation is to look good, these numbers were $54.1 \%, 21.6 \%$ and $24.3 \%$, respectively. All in all, $46.81 \%$ of girls and $27.59 \%$ of boys have tried to go on a diet at some point. As regards the BMI index of the students filling in the questionnaire, 33\% were underweight, $50.2 \%$ were normal weight and $16.8 \%$ were overweight. Out of the girls, $35.1 \%$ fall into the underweight category, $47.3 \%$ of them are in the normal weight category and $17.6 \%$ are overweight. As for the boys, 30.3\% are underweight, $53.8 \%$ are in the normal weight category and $15.9 \%$ are overweight. 
Veronika VÉGH, Gergely HORZSA, Zsolt B. NAGY, Gábor ELBERT, Henriette PUSZTAFALVI. Hungarian secondary school students' physical activity patterns with regard to gender

PROBLEMS

OF EDUCATION

IN THE $21^{\text {st }}$ CENTURY

Vol. 76, No. 5,2018

Striking differences were not found as to whether students of various BMI levels pay more or less attention to their daily calorie and nutritional intake. Having filtered out outliers, it can be seen on Figure 5 that, the more frequently a student does exercise, the more their BMI value decreases.

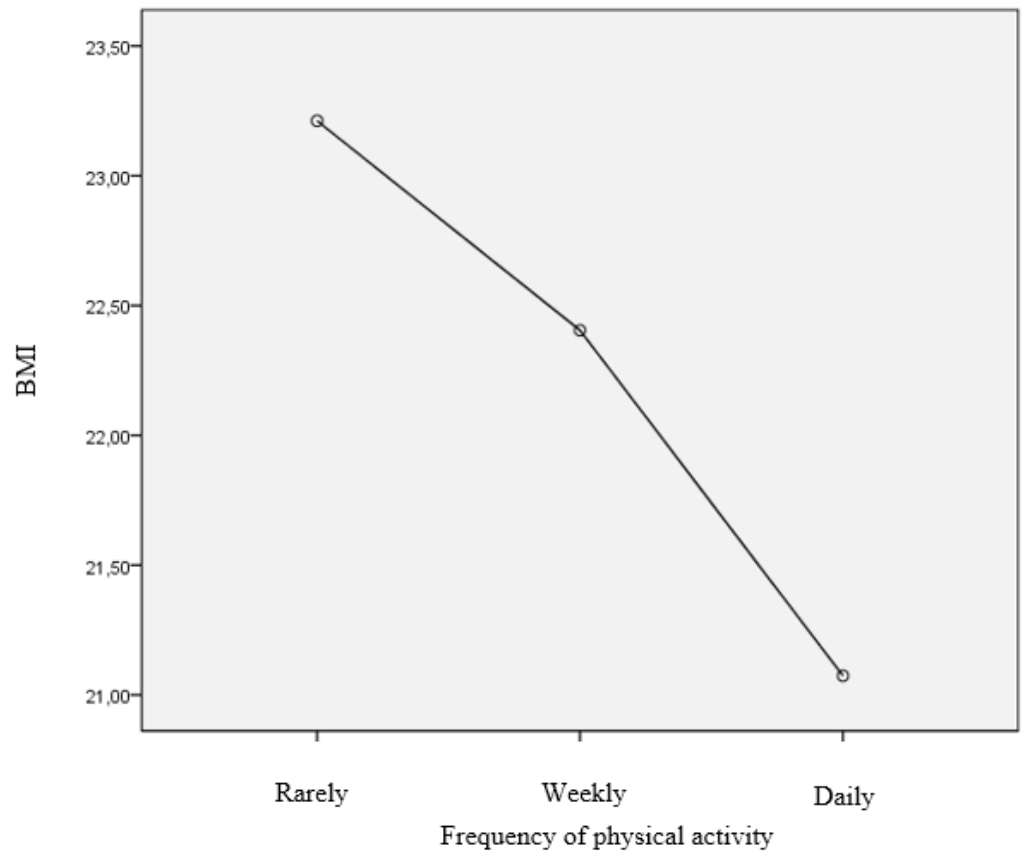

Figure 5: Frequency of physical activity and the students BMI values.

While answering the questions of the present research, it can be highlighted that more boys do sports daily or more times a week (70.4\%) than girls (63.8\%). Boys self-reported "love for sport' answers averages also got higher scores than the girls' averages (like sports very much: boys: $38.6 \%$, girls: $36.2 \%$ / like sport: boys: $26.2 \%$, girls: $17.6 \%$ ). When mapping their favorite subjects, PE was at second place in case of girls (17\%), while boys love PE the most $(24.8 \%)$ as a subject in school. Girls $(75.5 \%)$ would like to do physical activities more often than boys $(64.8 \%)$. The main reported causes of not having enough sport related activities are the lack of time and tiredness. The main sport motivating factors of the students are "having fun' (girls: $22.9 \%$, boys: $28.3 \%$ ) and "looking good' (girls: $22.3 \%$, boys: $18.6 \%$ ) for both genders.

Running showed to be the most favored activity by both genders (girls: $22.9 \%$, boys: $27.8 \%$ ), while boys also indicated football often as their preferred physical activity (22.9\%). Doing sport with the peers is more appealing for the boys (love to do sports with their friends: boys: $51.0 \%$, girls: $45.7 \%$ ), while more girls than boys love to do individual sports $(27.7 \%>$ $13.8 \%$ ). Outdoor activities are preferred by both genders (girls: $36.2 \%$, boys, $44.1 \%$ ) and also the gym got high averages (girls: $34 \%$, boys: $31.7 \%$ ). Both genders reported school as their least favored location for physical activities. Competitive sports are more popular among boys than girls. Even if $40.4 \%$ of girls and $44.8 \%$ of boys have tried in before, currently $26.2 \%$ of boys and $16.5 \%$ of girls are doing competitive sports.

As Table 3. indicates more girls consider healthy eating important $(30.3 \%)$ or very important $(16.5 \%)$ than boys $(27.6,15.9)$, although the majority of the students only occasionally pay attention to healthy eating (girls: $33.5 \%$, boys: $42.1 \%$ ). The BMI values showed that $33 \%$ of the students' were underweight, $50.2 \%$ fell into the normal category and $16.8 \%$ were overweight. More girls are underweight or overweight than boys $(35.1 \%>30.3 \% / 17.6 \%>15.9 \%)$. More boys fell into the normal BMI category $(53.8 \%>47.3 \%)$ than girls. The results showed 
Veronika VÉGH, Gergely HORZSA, Zsolt B. NAGY, Gábor ELBERT, Henriette PUSZTAFALVI. Hungarian secondary school students' physical activity patterns with regard to gender

that the majority of the students were non-smokers, but for the alcohol consumption boys appeared to be more abstinent than girls.

\section{Discussion}

The main aim of the research was to broaden the picture of the current sporting habits and lifestyle attributes of secondary school girl and boy students in order to provide a better picture about their needs. The results of the present study may support practicing teachers and professionals to be able to adjust the PE to these needs of the students and therefore the Paragraph 11 of $\S$ (6) A 27 Public Education Act may reach its fullest potential. The second aim was to provide data that could be useful for further international comparative analysis.

Physical inactivity increases the probability of higher BMI values among students (Muntaner-Mas et al., 2017). Obesity among children can have long-term health consequences (Must, 1996), therefore health education plays a crucial role in (Eithsdottir et al., 2008) shaping the lifestyle habits of the next generation. The present study supports the claim that boys have a more positive attitude to PE than girls (Koca \& Demirhan, 2004). Therefore, as was described before (Pano \& Markola, 2012), boys appear to be more active than girls.

Students find the amount of time they can dedicate to exercise insufficient. They believe the main reason for this is a lack of time (Pano \& Markola, 2012). This is supported by the opinions of the students in this research, according to which $75.5 \%$ of girls and $64.8 \%$ of boys would like to spend more time getting exercise than they were at the time the questionnaire was completed. The lack of time, tiredness, lack of money and lack of company were indicated as the biggest hindrance. Both boys and girls like doing sport with their friends the most (girls $45.7 \%$ and boys $51 \%$ ). Girls prefer to do exercise on their own (girls $27.7 \%$ and boys $13.8 \%$ ) whereas boys prefer team sports (boys $22.8 \%$ and girls $17.6 \%$ ). Children's physical activity levels, other lifestyle determiners and their connection to obesity have been widely investigated. Those children who were doing more physical activities had higher BMI values than the others (Koca, Akcam, Serdaroglu, \& Dereci, 2017). There is a positive relationship between the amount of time spent in front of the TV and BMI (Xu, Li, Ware, \& Oven, 2008). Food practices in schools are associated with body mass index (Kubik, Lytle, \& Story, 2005). In this study, the two main motivating factors for doing sports are the entertaining nature of sport and the fact that it can help them look better.

Based on the literature, girls go on diets more often than boys (Lowry et al., 2002) and this claim is supported by the fact that the number of adolescent girls who do sport in order to lose weight is higher (girls $13.8 \%$ and boys: 6.9\%). The collected data suggest that health preservation also motivates young people to do sport (girls $16.5 \%$ and boys $11.7 \%$ ).Competition is a more common motivation among boys (boys $13.11 \%$ and girls $11.1 \%$ ). A surprisingly small number of students mentioned parents as a motivation (girls $2.7 \%$ and boys $2.1 \%$ ) although the literature suggests that this is one of the key factors in establishing healthy eating habits and an active lifestyle among the next generation (Kubik et al. 2005). According to the findings, students prefer to pursue sport outdoors (girls $36.2 \%$ and boys $44.1 \%$ ). Gyms were also popular (girls 34\% and boys 31.4\%), however a surprisingly small number of students mentioned doing sport at school (girls $4.8 \%$ and boys 5.5\%), even though PE was the second favourite subject among girls (17.0\%) and one of the boys' favourite subjects $(24.8 \%)$. Baley R. (2006) proved that the 5 domains described previously (physical, lifestyle, affective, social, cognitive) that are the outcomes of children's PE and sport can have a significant contribution to children's development (Bailey, 2006). Previous studies have shown that competitive sports shape personalities significantly (Veliz et al., 2017). Based on this study, $44.8 \%$ of girls and $40.4 \%$ of boys have pursued competitive sport at some point, however larger number of boys $(26.2 \%)$ than girls $(16.5 \%)$ were pursuing competitive sport at the time when the questionnaire 
Veronika VÉGH, Gergely HORZSA, Zsolt B. NAGY, Gábor ELBERT, Henriette PUSZTAFALVI. Hungarian secondary school students' physical activity patterns with regard to gender

OF EDUC

IN THE $21^{\text {st }}$ CENTURY Vol. 76, No. 5, 2018

750

was completed. $43.1 \%$ of girls have never tried competitive sport. A correlation was found between the given answers on a 6-point Likert scale for the following sentences: 'I do a sport only if there is a possibility for competition' and 'I do sports regularly in order to maintain my health'. (Pearson correlation: .243, $\mathrm{p}=.000007$ ). When further observing the answers, $9.68 \%$ of girls who are currently pursuing competitive sport find healthy eating vital and the same percentage claim that they ignore it. A fairly high $48.39 \%$ of students always pay attention to healthy eating, whereas $32.26 \%$ only observe healthy eating habits when they have the time. On the whole, more than half of the girls who are currently pursuing sport $(48.39 \%+9.68 \%)$ regularly pay attention to healthy eating. Boys who are currently doing sport gave completely different answers. Considerably more boys than girls $(26.32 \%)$ pay disciplined attention to healthy eating but only $18.42 \%$ found it important. All in all, there are fewer boys who always pay attention to healthy eating than girls (boys $44.74 \%$ and girls $58.07 \%$ ). When examining the smoking and drinking habits of students who are currently doing competitive sport, according to the data, they consciously avoid these harmful activities. Based on the studies of Damsgaard et al. (2001), getting exercise does not affect body composition and adolescents' development (Damsgaard, Bencke, Matthiesen, Petersen, \& Müller, 2001), however it may have an effect on other areas including academic performance (Fox, Barr-Anderson, Neumark-Sztainer, \& Wall, 2010) and it also decreases the risk of developing diseases later on. The positive effect of sports on students' marks in mathematics and English has already been examined (Dyer et al., 2017). The findings indicate that there is a correlation between doing sport and girls' marks in biology. However, of all students, both boys and girls who are currently pursuing competitive sport had the best marks in biology, which could be because these students pay more attention to the subject or are motivated by extrinsic or intrinsic factors. Academic performance and team sport participation has also been examined in this study. The results did not show significant relationship between playing team sports and good performance at school.

Self-reported data showed that more girls go on diets than boys (boys $27.59 \%$ and girls $46.81 \%$ ), this claim is supported by Lowry et al. (2002). As for the BMI index, 33\% were underweight, $50.2 \%$ were normal weight and $16.8 \%$ were overweight. Out of the girls, $35.1 \%$ are underweight, $47.3 \%$ are in the normal weight category and $17.6 \%$ are overweight. As for the boys, $30.3 \%$ are underweight, $53.8 \%$ has ideal body weight and $15.9 \%$ are overweight. This study did not show any striking differences as to whether students of various BMI levels pay more or less attention to their daily calorie and nutritional intake. The self-esteem of high school students, particularly girls, is very low (Frost \& McKelvie, 2004). Many of them complement their diet with sport. The effects of different physical activities on adolescents is a popular research topic (Faigenbaum et al., 2009). To continue this research, it has been observed whether students who are doing sport or are trying to lose or maintain their weight pay attention to healthy eating. $44.1 \%$ of girls find healthy eating important and the same percentage pay attention to it when they have the time, whereas $11.8 \%$ ignore it. For boys, these percentages were $48.6 \%, 27 \%$ and $24.3 \%$, respectively. Male students are more extreme, as larger number of boys believe that healthy eating is important or ignore it. Among girls there is link between leading a weight loss lifestyle and smoking (Lowry et al., 2002). This research, however, did not reflect this, as $64.7 \%$ of girls who are trying to lose weight have never smoked, and $10.3 \%$ smoke daily, whereas $72 \%$ of boys who are trying to lose weight smoke, and $16.2 \%$ smoke daily.

\section{Conclusions}

This research described physical activity patterns and lifestyle attributes of Hungarian secondary school students. During PE lessons it is important for the teachers to know what kind of exercises should be done by the students that would best satisfy their needs. 
Veronika VÉGH, Gergely HORZSA, Zsolt B. NAGY, Gábor ELBERT, Henriette PUSZTAFALVI. Hungarian secondary school students' physical activity patterns with regard to gender

By offering boys more competitive exercises and girls more body-shaping practices, gender differences would be considered. Despite having PE lessons every day, students want to get more exercise, however the lack of time and tiredness prevent them from doing so. PE is the favourite lesson for the majority of the students, however school is their least favourite place to do exercise. By knowing this, the PE lessons could be adjusted to provide exercises that may reduce this dissatisfaction.

In spite of the fact, this research provides information about secondary school students sporting and lifestyle habits, further research and evaluation is needed to be able to draw a conclusion on the current state of health education in Hungarian high schools and the effect of such policies and to help us better understand the nature of these elements by means of national representative samples.

\section{References}

Bailey, R. (2006). Physical education and sport in schools: A review of benefits and outcomes. Journal of School Health, 76 (8), 397-401.

Damsgaard, R., J. Bencke, G. Matthiesen, J. H. Petersen, \& J. Müller (2001). Body proportions, body composition and pubertal development of children in competitive sports. Scandinavian Journal of Medicine \& Science in Sports, 11 (1), 54-60.

Dyer, A. M., A. L. Kristjansson, M. J. Mann, M. L. Smith \& J. P. Allegrante (2017). Sport participation and academic achievement: A longitudinal study. American Journal of Health Behavior, 41 (2), 179-185.

Eithsdottir, S. T., A. L. Kristjansson, I. D. Sigfusdottir \& J. P. Allegrante (2008). Trends in physical activity and participation in sports clubs among Icelandic adolescents. European Journal of Public Health, 18 (3), 289-293.

Faigenbaum, A. D., Kraemer, W. J., Blimkie, C. J., Jeffreys, I., Micheli, L. J., Nitka, M., \& Rowland, T. W. (2009). Youth resistance training: updated position statement paper from the national strength and conditioning association. Journal of Strength \&Conditional Research, 23 (5 Suppl), S60-79.

Fox, C. K., Barr-Anderson, D., Neumark-Sztainer, D., \& Wall, M. (2010). Physical activity and sports team participation: Associations with academic outcomes in middle school and high school students. Journal of School Health, 80 (1), 31-37.

Frost, J., \& McKelvie, S. (2004). Self-esteem and body satisfaction in male and female elementary school, high school, and university students. Sex Roles, 51 (1), 45-54.

Koca, C., \& Demirhan, G. (2004). An examination of high school students' attitudes toward physical education with regard to sex and sport participation. Perceptual and Motor Skills, 98 (3), 754-758.

Koca, T., Akcam, M., Serdaroglu, F., \& Dereci, S. (2017). Breakfast habits, dairy product consumption, physical activity, and their associations with body mass index in children aged 6-18. European Journal of Pediatrics, 176 (9), 1251-1257.

Kropski, J. A., Keckley, P. H., \& Jensen, G. L. (2008). School-based obesity prevention programs: An evidence-based review. Obesity, 16 (5), 1009-1018.

Kubik, M. Y., Lytle, L., \& Fulkerson, J. A. (2005). Fruits, vegetables, and football: Findings from focus groups with alternative high school students regarding eating and physical activity. Journal of Adolescent Health, 36 (6), 494-500.

Lowry, R., Galuska, D. A., Fulton, J. E., Wechsler, H., \& Kann, L. (2002). Weight management goals and practices among U.S. high school students: Associations with physical activity, diet, and smoking. Journal of Adolescent Health, 31 (2), 133-144.

Meszlényi, E., Borbélyi, Sz., Seregi, E., Morvay-Sey, K., \& Rétsági, E. (2017). A mindennapos testnevelés néhány kérdésének vizsgálata [Analysis of some questions related to everyday physical education]. In Rétsági (Ed.), Sport- és Egészségtudományi Füzetek, 1(1) 8-18, Pécs, PTE http://etk.pte.hu/public/upload/files/Sport_es_egtudomanyi_fuzetek/Sport_Egtud1evf1szam.pdf.

Morvay-Sey, K., \& Rétsági, E. (2017). A mindennapos testnevelés gyakorlati megvalósulásának vizsgálata a pécsi iskolákban [Practical accomplishment of everyday physical education in schools of city of Pécs]. In Rétsági (ed.): 1(1) 19-29, Pécs, PTE http://etk.pte.hu/public/upload/ files/Sport_es_egtudomanyi_fuzetek/Sport_Egtud1 evf1szam.pdf.

\author{
PROBLEMS \\ OF EDUCATION \\ IN THE $21^{\text {st }}$ CENTURY \\ Vol. 76, No. 5, 2018 \\ 751
}


Veronika VÉGH, Gergely HORZSA, Zsolt B. NAGY, Gábor ELBERT, Henriette PUSZTAFALVI. Hungarian secondary school students' physical activity patterns with regard to gender

\section{PROBLEMS \\ OF EDUCATION \\ IN THE $21^{\text {st }}$ CENTURY \\ Vol. 76, No. 5, 2018}

752

Muntaner-Mas, A., Vidal-Conti, J., Cantallops, J., Borràs, P. A., \& Palou, P. (2017). Obesity and physical activity patterns among Balearic Islands children and adolescents: A cross-sectional study. Journal of Human Sport end Exercise, 12 (2), 333-348. doi:10.14198/jhse.2017.122.10.

Must, A. (1996). Morbidity and mortality associated with elevated body weight in children and adolescents. American Journal of Clinical Nutrition, 63 (3 Suppl), 445S-7S.

Németh, Á (2014). Fizikai aktivitás és képernyőhasználat [Physical activities and monitor use]. In Németh, Á., \& Költő, A. (Eds), Egészség és egészségmagatartás iskoláskorban [Health and health behaviours during school age]. Retrieved from http://mek.oszk.hu/16100/16119/16119.pdf.

Kubik, M. Y., Lytle, L. A., \& Story, M. (2005). Schoolwide food practices are associated with body mass index in middle school students. Archives of Pediatrics \& Adolescent Medicine, 159 (12), 11111114.

OGYEI [Hungarian National Institution of Child Health] (2014). Összefoglaló jelentés a 2012/2013. tanévben végzett iskola-egészségügyi munkáról [Summarizing report on medical work in schools in 2012-2013]. Retgrieved from http://www.ogyei.hu/upload/files/2012_2013_evi_ iskolaegeszsegugyi_jelentes.pdf.

Paakkari, L., Kokko, S., Villberg, J., Paakkari, O., \& Tynjala, J. (2017). Health literacy and participation in sports club activities among adolescents. Scandinavian Journal of Public Health, 45 (8). doi: $10.1177 / 1403494817714189$.

Rowland, T. W. (2007). Promoting physical activity for children's health: rationale and strategies. Sports Medicine, 37 (11), 929-936.

Uvacsek, M., \& Pusztafalvi, H. (2018). The 11-18 years old Hungarian youth's nutritional status and some health-determinants from the 2010-2014 HBSC Study. Magyar Sporttudományi Szemle, (1).

Veliz, P., Schulenberg, J., Patrick, M., Kloska, D., McCabe, S. E., \& Zarrett, N. (2017). Competitive sports participation in high school and subsequent substance use in young adulthood: Assessing differences based on level of contact. International Review for the Sociology of Sport, 52 (2), 240-259.

Xu, F., Li, J., Ware, R., \& Owen, N. (2008). Associations of television viewing time with excess body weight among urban and rural high-school students in regional mainland China. Public Health Nutrition, 11 (9), 891-896.

Received: June 20, 2018

Accepted: October 05, 2018

Veronika Végh

Zsolt B. Nagy

Gábor Elbert

Henriette Pusztafalvi
MSc, PhD Student Faculty of Health Sciences, University of Pecs, Vörösmarty Mihály u. 4, 7621, Pecs, Hungary.

E-mail: vghveronika@yahoo.com

Institute of Sociology and Social policy, Corvinus University, Budapest, Hungary. E-mail: horzsagergely@gmail.com

Guppi Consulting Ltd, Budapest, Hungary.

E-mail: dr.nagy.zsolt@gmail.com

Faculty of Health Sciences, University of Pecs, Pecs, Hungary.

E-mail: elberteam@gamil.com

Faculty of Health Sciences, University of Pecs, Pecs, Hungary.

E-mail: pusztafalviheni@gmail.com 